\title{
Hubungan Self Management Dengan Kualitas Hidup Pasien Diabetes Melitus Di Puskesmas Landasan Ulin
}

\author{
Solikin, Muhammad Rizki Heriyadi \\ Universitas Muhammadiyah Banjarmasin \\ Fakultas Keperawatan dan Ilmu Kesehatan \\ Korespondensi Email : solikin@umbjm.ac.id
}

DOI: $10.33859 / \mathrm{dksm} . v 1111.545$

\begin{abstract}
Abstrak
Latar Belakang: Gaya hidup tidak sehat dewasa ini sedang menjadi pembicaraan, seperti mengkonsumsi junk food, minuman bersoda, dan malas berolahraga, hal ini merupakan masalah kesehatan yang harus diatasi, apabila tidak akan terjadi kerusakan metabolisme didalam tubuh, Peningkatan jumlah kasus diabetes melitus. Diabetes melitus merupakan gangguan metabolisme yang ditandai dengan tingginya kadar gula darah sebagai akibat insufisisiensi fungsi insulin.

Tujuan: untuk mengetahui hubungan self management dengan kualitas hidup pasien diabetes melitus di Puskesmas Landasan Ulin tahun 2019.

Metode : penelitian menggunakan metode analitik, Populasi: pasien diabetes melitus tanpa komplikasi, dan berdomisili di wilayah kerja Puskesmas Landasan Ulin dalam enam bulan terakhir tahun 2019 sebanyak 114 orang. Sampel penelitian sebanyak 98 partisipan. Pengambilan sampel menggunakan metode simple random sampling. Data dikumpulkan menggunakan kuesioner dan dianalisis menggunakan uji spearman rank.

Hasil : penelitian menunjukan sebagian besar self management dalam kategori cukup (48\%), sedangkan kualitas hidup dalam kategori cukup $(57,1 \%)$, hasil analisis bivariat menggunakan spearman rank menunjukkan $p$ value $0,000(\mathrm{p}<0,05)$ hal ini menunjukkan bahwa ada hubungan antara self management dengan kualitas hidup pasien diabetes melitus di Puskesmas Landasan Ulin tahun 2019. self management seperti kontrol rutin gula darah, pengambilan obat rutin, diet diabetes melitus, dan aktivitas fisik, sangat penting dilakukan untuk mencegah komplikasi pada pasien diabetes melitus dan akan meningkatkan kualitas hidup pasien diabetes melitus

Simpulan : self management seperti kontrol rutin gula darah, pengambilan obat rutin, diet diabetes melitus, dan aktivitas fisik, sangat penting dilakukan untuk mencegah komplikasi pada pasien diabetes melitus dan akan meningkatkan kualitas hidup pasien diabetes melitus
\end{abstract}

Kata Kunci : diabetes melitus, kualitas hidup, self management, 
The Relationship OfSelf-Management With The Quality Of Life Of Diabetes Mellitus Patients At Puskesmas Landasan Ulin

\begin{abstract}
Background: Today's unhealthy lifestyle is being discussed, such as consuming junk food, soft drinks, and being lazy to exercise, these are health problems that must be overcome, otherwise there will be metabolic damage in the body, an increase in the number of diabetes mellitus cases. Diabetes mellitus is a metabolic disorder characterized by high blood sugar levels as a result of insufficient insulin function.

Objective: to determine the relationship between self-management and quality of life for diabetes mellitus patients at the Puskesmas Landasan Ulin in 2019.

Methods: the study used an analytical method, Population: patients with diabetes mellitus without complications, and residing in the work area of the Puskesmas Landasan Ulin in the last six months of 2019 were 114 people. The sample in this study was 98 participants. Sampling using simple random sampling method. Data were collected using a questionnaire and analyzed using the Spearman rank test.

Results: the study showed that most of the self-management was in the sufficient category (48\%), while the quality of life was in the sufficient category (57.1\%), the results of the bivariate analysis using the Spearman rank showed a $p$ value of $0.000(p<0.05)$, this indicates that there is a relationship between self management and the quality of life of diabetes mellitus patients at the Puskesmas Landasan Ulin in 2019. self management such as routine blood sugar control, routine drug taking, diabetes mellitus diet, and physical activity is very important to prevent complications in diabetes mellitus patients and will improve the quality of life of patients with diabetes mellitus

Conclusion: self-management such as routine control of blood sugar, routine drug taking, diabetes mellitus diet, and physical activity is very important to prevent complications in diabetes mellitus patients and will improve the quality of life of diabetes mellitus patients.
\end{abstract}

Keywords: diabetes mellitus, quality of life, self management

\section{Pendahuluan}

Gaya hidup tidak sehat dewasa ini sedang hangat menjadi pembicaraan, seperti mengkonsumsi junk food, minuman bersoda, dan malas berolahraga. Kebiasaan ini menjadi trend baru yang tidak bisa dilepaskan dari kehidupan sehari-hari. Perubahan gaya hidup ini berdampak terhadap perubahan pola penyakit yang terjadi di masyarakat, dan gaya hidup seperti ini terjadi di negara maju dan negara berkembang. Hal ini merupakan masalah kesehatan yang cukup serius dan harus diatasi, apabila tidak diatasi maka akan terjadi terjadi kerusakan metabolisme didalam tubuh, dimana hal ini akan mengakibatkan meningkatnya jumlah kasus diabetes melitus.

International Diabetes Federation (IDF) menyebutkan bahwa penderita diabetes melitus merupakan masalah kesehatan yang besar. IDF juga melaporkan bahwa pada tahun 2016 penderita diabetes melitus ada 422 juta jiwa, dan mengalami peningkatan pada tahun 2017 dimana penderita diabetes di dunia menjadi 425 juta jiwa. Hal ini diperkuat lagi oleh American Diabetes Association (ADA) tentang penderita diabetes melitus di seluruh dunia, dimana pada tahun 2018 tercatat ada 
500 juta jiwa yang menderita diabetes melitus di seluruh dunia. Berdasarkan data yang diperoleh tersebut diketahui bahwa penderita diabetes melitus di seluruh dunia mengalami peningkatan setiap tahunnya.

Hasil Riskesdas menyatakan bahwa penderita diabetes melitus di Indonesia mengalami peningkatan dimana pada tahun 2016 penderita diabetes melitus ada 9,1 juta jiwa. Hal ini juga diperkuat oleh laporan IDF akan Indonesia dimana pada tahun 2017 ada 10,2 juta jiwa menderita diabetes melitus, dan pada tahun 2018 mengalami peningkatan menjadi 16 juta jiwa menderita diabetes melitus di Indonesia (IDF, 2018). Berdasarkan data yang diperoleh tersebut diketahui bahwa angka penderita diabetes melitus di Indonesia selalu bertambah setiap tahunnya. Dinas Kesehatan Provinsi Kalimantan Selatan mencatat penderita diabetes melitus pada tahun 2016 berjumlah 12.466 jiwa, mengalami peningkatan pada tahun 2017 menjadi 46.158 jiwa, dan pada tahun 2018 menjadi 86.811 jiwa penderita diabetes melitus di Kalimantan Selatan. Berdasarkan data yang diperoleh tersebut diketahui bahwa penderita diabetes melitus di Kalimantan Selatan setiap tahunnya mengalami peningkatan (Dinkes Prov. Kalsel, 2019). Penderita diabetes melitus di Banjarbaru juga mengalami peningkatan dari tahun ke tahun dimana pada tahun 2016 ada 1.112 jiwa penderita diabetes melitus, mengalami peningkatan menjadi 4.049 jiwa pada tahun 2017, dan pada tahun 2018 penderita diabetes melitus di Banjarbaru menjadi 6.339 jiwa (Dinkes Kota Banjarbaru, 2019). Berdasarkan data dari Puskesmas Landasan Ulin juga menunjukan angka peningkatan penderita diabetes melitus, dimana pada tahun 2016 ada 266 penderita diabetes mellitus, mengalami peningkatan pada tahun 2017 menjadi 381 orang penderita diabetes melitus, dan pada tahun 2018 mengalami peningkatan menjadi 505 orang penderita diabetes melitus di Puskesmas Landasan Ulin (Puskesmas Landasan Ulin, 2019). Berdasarkan data yang diperoleh tersebut diketahui bahwa penderita diabetes melitus di Puskesmas Landasan Ulin setiap tahunnya mengalami peningkatan.

Diabetes melitus dapat dicegah atau kejadiannya dapat ditunda dan dapat dikontrol, dengan tatalaksana pengobatan yang optimum (IDF, 2015). Dimana semakin tinggi kualitas hidup pasien diabetes melitus maka pencegahannya akan penyakit diabetes melitus juga baik, namun kenyataannya penurunan kualitas hidup pada pasien diabetes melitus sering diikuti dengan ketidaksanggupan pasien tersebut dalam melakukan self management secara mandiri. Ketidaksanggupan pasien diabetes melitus dalam melakukan self management dapat mempengaruhi kualitas hidup dari segi kesehatan fisik, kesejahteraan psikologis, hubungan sosial, dan hubungan dengan lingkungan.

Studi pendahuluan yang dilakukan peneliti di Puskesmas Landasan Ulin pada tanggal 17-19 
Juni 2019 melalui wawancara kepada 10 orang yang didiagnosa diabetes melitus didapatkan data 7 dari 10 orang $(70 \%)$ penderita diabetes melitus tidak peduli akan penyakitnya, meraka mengatakan jarang memeriksakan diri, jarang kontrol gula darah rutin perbulan, jarang olah raga teratur, tidak melaksanakan diet diabetes melitus, dan mereka juga mengatakan putus dalam minum obat diabetes melitus, mereka mengatakan akan berobat apabila tubuh sudah menunjukan gejala yang parah, bahkan mereka mengatakan pasrah akan kehidupannya. Akan tetapi ada 3 orang (30\%) yang melaksanakan kontrol rutin perbulan, pengambilan obat rutin, dan cek gula darah, namun mereka mengatakan sangat susah untuk melaksanakan diet diabetes dan olah raga diabetes melitus yang rutin.

\section{Metode}

\section{a. Desain Penelitian}

Jenis penelitian yang digunakan dalam penelitian ini adalah cross sectional.

\section{b. Definisi Operasional}

1) Self management: Suatu cara seseorang untuk mengontrol, mengolola, serta mengatur diri mereka sendiri dalam penanganan diabetes melitus.

2) Kualitas hidup: Suatu tingkatan keadaan baik/buruknya seseorang terhadap keadaan hidupnya baik secara fisik, psikologis, hubungan sosial, dan lingkungan seseorang.
Populasi dalam penelitian ini pasien diabetes melitus tanpa komplikasi/perlukaan, dan pasien yang berdomisili diwilayah kerja Puskesmas Landasan Ulin dalam enam bulan terakhir tahun 2019, jumlah sampel sebanyak 98 partisipan, dengan teknik simple random sampling.

\section{d. Tempat dan Waktu Penelitian}

Penelitian dilaksanakan di Puskesmas Landasan Ulin, yang terdiri dari 2 Kelurahan yaitu: Kelurahan Landasan Ulin Utara, dan Kelurahan Landasan Ulin Tengah.

\section{e. Teknik dan Alat Pengumpulan Data}

Teknik pengumpulan data yang digunakan peneliti yaitu menggunakan kuesioner.

\section{f. Teknik Analisa Data}

Analisa data yang digunakan peneliti ini adalah uji Spearman Rank

\section{Hasil}

Distribusi Frekuensi Self Management

Berikut ini di deskripsikan tentang distribusi frekuensi self management partisipan di Puskesmas Landasan Ulin Tahun 2019

Tabel 1. Distribusi Frekuensi Partisipan Menurut Self Management

\begin{tabular}{cccc}
\hline No & $\begin{array}{c}\text { Self } \\
\text { Management }\end{array}$ & $\mathrm{f}$ & $\%$ \\
\hline 1 & Baik & 32 & 32,7 \\
2 & Cukup & 47 & 48 \\
3 & Kurang & 19 & 19,4 \\
\hline & Total & 98 & 100 \\
\hline
\end{tabular}

\section{c. Populasi, Sampel, dan Sampling}


Dari table 1 Dapat diketahui bahwa sebagian besar self management pastisipan adalah pada kategori cukup sebanyak 47 partisipan (48\%), dan self management kurang sebanyak 19 partisipan (19,4\%).

Distribusi Frekuensi Kualitas Hidup

Berikut ini di deskripsikan tentang distribusi frekuensi kualitas hidup partisipan di Puskesmas Landasan Ulin Tahun 2019

Tabel 2. Distribusi Frekuensi Partisipan Menurut Kualitas Hidup

\begin{tabular}{clcc}
\hline No & Kualitas Hidup & f & $\%$ \\
\hline 1 & Baik & 23 & 23,5 \\
2 & Cukup & 56 & 57,1 \\
3 & Kurang & 19 & 19,4 \\
\hline & Total & 98 & 98 \\
\hline
\end{tabular}

Dari table 2 Dapat diketahui bahwa sebagian besar kualitas hidup partisipan adalah pada kategori cukup yaitu sebanyak 56 partisipan (57,1 \%), dan kualitas hidup kurang sebanyak 19 partisipan $(19,4 \%)$.

Berikut ini di deskripsikan tentang hubungan self management dengan kualitas hidup pasien diabetes melitus di Puskesmas Landasan Ulin tahun 2019.

Hubungan self management dengan kualitas hidup pasien diabetes melitus di Puskesmas Landasan Ulin tahun 2019 dijelaskan dibawah ini sebagai berikut:

Tabel 3. Hubungan self management dengan kualitas hidup pasien diabetes melitus di Puskesmas Landasan Ulin tahun 2019

\begin{tabular}{|c|c|c|c|c|c|c|c|c|c|}
\hline \multirow{3}{*}{$\begin{array}{c}\mathrm{N} \\
\mathrm{o}\end{array}$} & \multirow{3}{*}{$\begin{array}{c}\text { Self } \\
\text { Managem } \\
\text { ent }\end{array}$} & \multicolumn{6}{|c|}{ Kualitas Hidup } & \multirow[t]{3}{*}{$\sum$} & \multirow[t]{3}{*}{$\%$} \\
\hline & & \multicolumn{2}{|c|}{ Baik } & \multicolumn{2}{|c|}{ Cukup } & \multicolumn{2}{|c|}{ Kurang } & & \\
\hline & & $\mathrm{n}$ & $\%$ & $\mathrm{~N}$ & $\%$ & $\mathrm{n}$ & $\%$ & & \\
\hline \multirow[t]{2}{*}{1} & Baik & 1 & 19 , & 1 & 13 , & 0 & 0 & 3 & 32 , \\
\hline & & 9 & 4 & 3 & 3 & & & 2 & 7 \\
\hline \multirow[t]{2}{*}{2} & Cukup & 4 & 4,1 & 3 & 35 , & 8 & 8,2 & 4 & 48 \\
\hline & & & & 5 & 7 & & & 7 & \\
\hline \multirow[t]{2}{*}{3} & Kurang & 0 & 0 & 8 & 8,2 & 1 & 11 , & 1 & 19 , \\
\hline & & & & & & 1 & 2 & 9 & 4 \\
\hline
\end{tabular}

\begin{tabular}{rcccccccc}
\hline & 2 & 32, & 5 & 57, & 1 & 19, & 9 & 10 \\
3 & 5 & 6 & 1 & 9 & 4 & 8 & 0 \\
\hline \multicolumn{10}{c}{$p$ value $=0,000$} \\
\hline Hasil analisis
\end{tabular}

Hasil analisis dengan menggunakan uji statistik Spearman Rank menunjukkan $p$ value 0,000 nilai tersebut secara statistik bermakna $(\mathrm{p}<0,05)$ hal ini menunjukkan bahwa ada hubungan antara self management dengan kualitas hidup pasien diabetes melitus di Puskesmas Landasan Ulin tahun 2019, yang diartikan semakin baik self management maka akan semakin baik kualitas hidup pasien diabetes melitus.

\section{Pembahasan}

\section{a. Self Management Pasien Diabetes} Melitus Di Puskesmas Landasan Ulin

Sebagian besar self management pastisipan adalah pada kategori cukup (48\%), dikarenakan beberapa hal salah satunya yang di sebutkan dalam PERKENI adalah pendidikan dimana Self management efektif didapatkan jika seseorang mempunyai keterampilan dan pengetahuan untuk melakukan pengelolaan diabetes melitus secara mandiri (PERKENI, 2015). Hal ini sejalan dengan penelitian yang dilakukan oleh peneliti dimana sebagian besar pendidikan partisipan adalah SLTA (48\%), sedangkan yang paling sedikit tidak sekolah (4,1\%). Pendidikan dalam hal ini mempenyai arti penting, dimana orang dengan pendidikan yang tinggi akan mempunyai banyak pengetahuan dan pemahaman mengenai 
kesehatan, maka orang tersebut mengerti dalam hal memelihara kesehatannya. Sedangkan pada tingkat pendidikan lebih rendah, akses terhadap informasi tentang kesehatannya minimal, sehingga kadang-kadang tidak menyadari gejala awal diabetes mellitus (Pradono \& Sulistyowati 2013). Menurut asumsi peneliti self management dipengaruh oleh banyak faktor salah satunya pendidikan dimana tingkat pendidikan dapat mempengaruhi pengetahuan, sehingga pengetahuan sangat diperlukan bagi penderita diabetes melitus, mengingat penyakit diabetes melitus adalah penyakit kronik yang hanya bisa di optimalkan, dengan pengetahuan yang baik maka penatalaksanaan dalam perawatan pasien diabetes melitus dapat terlaksana secara optimal.

\section{b. Kualitas Hidup Pasien Diabetes}

\section{Melitus Di Puskesmas Landasan Ulin}

Sebagian besar kualitas hidup partisipan adalah pada kategori cukup (57,1\%), dikarenakan pasien diabetes melitus sudah mengerti dalam merespon diri mereka, hal ini dapat dilihat pada self management pasien diabetes melitus di Puskesmas Landasan Ulin dalam pilar kontrol kadar gula darah rutin di pelayanan kesehatan dalam kategori baik (43,9\%). Hal ini juga didukung oleh penelitian Hartati et al (2019) dengan hasil yang sama yaitu sebagian besar partispan memiliki kualitas hidup yang cukup (63,9\%) (Hartati, et al 2019). Kualitas hidup tersebut merupakan gambaran respon individu secara fisik, psikologis, sosial terhadap suatu penyakit yang mempengaruhi penilaian individu terhadap tingkat kepuasan kesehatannya dalam lingkungan kehidupannya (Patrick dan Erickson, 1993 dalam Handayani, 2006). Menurut asumsi peneliti respon individu terhadap suatu penyakit akan mempengaruhi kualitas hidup seseorang, oleh karena itu perlu adanya pandangan terhadap suatu penyakit yang mengacu pada peningkatan kualias hidup seseorang, sehingga pengobatan untuk penyakit diabetes melitus akan meningkatkan kualitas hidup.

\section{Hubungan Self Management Dengan}

\section{Kualitas Hidup Pasien Diabetes} Melitus Di Puskesmas Landasan Ulin Tahun 2019

Self management pasien diabetes melitus di Puskesmas Landasan Ulin memiliki hubungan dengan kualitas hidup, hal ini sesuai dengan hasil uji statistik menggunakan spearman rank didapatkan hasil $p$ value $0,000<0,05$ yang artinya jika self management dilakukan secara teratur maka kualitas hidup penderita diabetes melitus akan 
meningkat. Hasil penelitian ini sesuai dengan penelitian yang telah dilakukan oleh Suryadi (2017) dimana terdapat hubungan self management dengan kualitas hidup pasien diabetes melitus di Rumah Sakit Tingkat II Dr. Soeproen Malang (Suryadi, 2017). Hal ini sejalan dengan Onuoha dan Ezenwaka 2014 dalam Hidayanti (2017) yang menuliskan bahwa diabetes self management merupakan salah satu strategi yang tepat untuk mengendalikan penyakit diabetes melitus (Hidayanti, 2017). Menurut asumsi peneliti dengan meningkatkan self management yaitu kontrol gula darah rutin, pengambilan obat rutin, diet diabetes melitus, dan melaksanakan aktifitas fisik, maka kualitas hidup pasien diabetes melitus akan meningkat.

Self management seperti kontrol rutin gula darah, pengambilan obat rutin, diet diabetes melitus, dan aktivitas fisik, sangat penting dilakukan untuk mencegah komplikasi pada pasien diabetes melitus dan akan meningkatkan kualitas hidup pasien diabetes melitus, mengingat beberapa kelebihan dari self management adalah membantu individu untuk dapat mengelola diri secara optimal, membantu melibatkan individu secara aktif, membantu meletakkan tanggung jawab perubahan sepenuhnya kepada individu, membantu individu untuk dapat mengelola diri baik pikiran, perasaan dan perbuatan sehingga dapat berkembang secara optimal, membantu melibatkan individu secara aktif maka akan menimbulkan perasaan bebas dari kontrol orang lain. Tanggung jawab sangat diperlukan untuk perubahan sepenuhnya kepada individu, maka dia akan menganggap bahwa perubahan yang terjadi karena usahanya sendiri dan lebih tahan lama, sehingga komplikasi seperti ketoasidosis, hyperglycemic hyperosmolar syndrome (HHS), diabetic foot, bahkan sepsis dapat dicegah dan akan meningkatkan kualitas hidup pasien diabetes melitus.

\section{Simpulan}

a. Sebagian besar self management partisipan pada kategori cukup yaitu sebanyak 47 orang (48\%).

b. Sebagian besar kualitas hidup partisipan pada kategori cukup yaitu sebanyak 56 orang $(57,1 \%)$.

c. Hasil analisis dengan menggunakan uji statistik Spearman Rank menunjukkan $p$ value sebesar 0,000 , nilai tersebut secara statistik bermakna $(p<0,05)$ hal ini menunjukkan bahwa ada hubungan antara self management dengan kualitas hidup pasien diabetes melitus di Puskesmas Landasan Ulin tahun 2019. 


\section{Saran}

Bagi peneliti lain diharapkan dapat mengembangkan lebih lanjut pada penelitian sejenis, seperti membahas tentang faktor lama menderita dan dukungan keluarga dalam kaitannya dengan peningkatan kualitas hidup pasien diabetes melitus.

\section{Daftar Pustaka}

American Diabetes Association. 2016. Standar of Medical Care in Diabetes. Dunia: ADA.

American Diabetes Association. 2017. 2017 National Standards for Diabetes Self Management Education and Support. ADA: Diabetes Care.

Dinas Kesehatan Kota Banjarbaru. 2019. Profil Kesehatan Kota Banjarbaru 2018. Banjarbaru: Dinas Kesehatan Kota Banjarbaru.

Dinas Kesehatan Provinsi Kalimantan Selatan. 2019. Profil Kesehatan Provinsi Kalimantan Selatan. Banjarmasin: Dinas Kesehatan Provinsi Kalimantan Selatan.

Handayani, Y. S. (2006). Indeks Pengukuran Disabilitas Dan Prediksi Kualitas Hidup Pada Masyarakat Lanjut Usia Di DKI Jakarta. Disertasi Fakultas Kesehatan Masyarakat: Universitas Indonesia.

Hartati, I., Agus, D. P., \& M. Rizky R. 2019. Hubungan Self Care dengan Kualitas Hidup Pasien Diabetes mellitus Di Poli Penyakit dalam RSUD Langsa. Aceh: Jurnal Pendidikan dan Praktik Kesehatan (vol. 2, no. 2) eISSN: 2655-027.

Hidayanti. L. 2017. Hubungan Dukungan Keluarga Dengan Self Management Pada Penderita Diabetes Melitus Tipe 2. Yogyakarta: FKIK UMY.

Nursalam. 2016. Metodologi Penelitian Ilmu Keperawatan: Pendekatan Praktik Edisi 4. Jakarta: Salemba Medika.
Perkumpulan Endokrinologi Indonesia. 2015. Pengelolaan dan Pencegahan Diabetes Melitus di Indonesia. Jakarta: PERKENI.

Pradono, J., \& Sulistyowati, N. (2013). Hubungan Antara Tingkat Pendidikan , Pengetahuan Tentang Kesehatan Lingkungan , Perilaku Hidup Sehat Dengan Status Kesehatan Studi Korelasi Pada Penduduk Umur 10 - 24 Tahun Di Jakarta Pusat. Buletin penelitian Sistem Kesehatan, 17 (1).

Puskesmas Landasan Ulin. 2019. Profil Tahunan Puskesmas Landaasan Ulin. Landasan Ulin: Puskesmas Landasan Ulin.

RISKESDAS. 2018. Hasil Utama Riskesdas 2018. Jakarta: Badan Penelitian dan Pengembangan Kesehatan.

Suryadi, W. (2017). Hubungan Self Management Dengan kualitas Hidup Pasien Diabetes Melitus Di Rumah Sakit Tingkat II Dr. Soepraoen Malang. Jurnal ilmu keperawatan universitas brawijaya ISSN 2598-849 